\title{
Generations $X$ and $Y$ Attitudes toward Fresh Flowers as Gifts: Implications for the Floral Industry
}

\author{
Alicia L. Rihn ${ }^{1}$ \\ Department of Horticultural Science, University of Minnesota, 1970 Folwell \\ Avenue, St. Paul, MN 55108
}

Chengyan Yue ${ }^{2,4}$

Departments of Horticultural Science and Applied Economics, Bachman

Endowed Chair in Horticultural Marketing, University of Minnesota, 1970

Folwell Avenue, St. Paul, MN 55108

\section{Bridget Behe ${ }^{3}$}

Department of Horticulture, Michigan State University, A288 Plant and Soil Science Building, East Lansing, MI 48824

\section{Charles Hall ${ }^{3}$}

Department of Horticultural Sciences, Texas A\&M University, 202 Horticulture Forest Science Building, College Station, TX 77843-2133

Additional index words. advertising, consumer attitudes, marketing, mature stage, product life cycle

\begin{abstract}
Demand for fresh-cut flowers and floral products has been decreasing in recent years, particularly among young consumers. The objectives of this study were to explore Generations $X$ and Y's positive and negative attitudes toward flowers as gifts; explore differences in perceptions about price, product, place, and promotions among Generations $\mathrm{X}$ and $\mathrm{Y}$ to determine the best marketing techniques to reach them; and determine what actions the floral industry can take to improve Generations $X$ and $Y$ 's use of flowers as gifts. Participants were recruited in Minneapolis and St. Paul, MN, and Lansing and East Lansing, MI. Participants were asked to complete a questionnaire and participate in a focus group discussion. An ordered probit model was used to analyze the data. Results showed that younger consumers were dissatisfied with several floral product attributes, including short longevity, lack of trendiness, relative high cost, lack of appropriateness, and lack of uniqueness. Results also indicate that younger consumers perceived that their friends do not enjoy floral gifts. Additionally, younger consumers viewed floral advertisements less frequently and considered floral gifts difficult to purchase, resulting in decreased awareness and interest. Overall, most participants felt that in-store sales or discounts, greater flower longevity, more price ranges, and trendier arrangements/flowers would increase their use of fresh flowers as gifts.
\end{abstract}

Previous research has shown the floriculture retail industry is in the mature stage in the product life cycle resulting in decreased profits and sales (Behe et al., 2003). Supporting research suggests the overall demand for fresh-cut flowers and floral products is decreasing compared with several years ago, particularly among younger consumers, indicating they have needs that are unmet by available floral products (American Floral Endowment, 2008; Burke, 2007; Silvergleit, 2004). One technique to reinvigorate sales is to implement

\footnotetext{
Received for publication 12 Oct. 2010. Accepted for publication 1 Mar. 2011.

We gratefully acknowledge funding from the Floral Marketing Research Fund.

${ }^{1} \mathrm{PhD}$ Student.

${ }^{2}$ Assistant Professor.

${ }^{3}$ Professor.

${ }^{4}$ To whom reprint requests should be addressed; e-mailyuechy@umn.edu.
}

an innovative marketing strategy; that is, to introduce the product to a segment that currently does not use the product. Lack of use among younger consumers gives marketers an opportunity to stimulate purchases among members of this age cohort, potentially shifting sales of fresh floral products from the mature stage back to the growth stage (Kerin et al., 2009). Based on this information, the current study explores the needs of different age cohorts to better understand how to find and attract new, younger consumers to shift fresh floral products back to the more profitable growth stage.

Consumers are not homogenous and show different attitudes and preferences toward products they are considering for purchase. Because of this, individual product attributes also tend to vary in importance among consumers. Earlier research suggests that market segmentation works well to centralize consumer needs and attract new customers
(Oppenheim, 2000). Market segmentation groups consumers with similar preferences and who will frequently respond similarly to specific but similar market mixes and stimuli (Oppenheim, 2000). Often segments are based on demographics such as age or gender (Kerin et al., 2009; Oppenheim, 2000). Age has been successfully used in studies to segment consumers and show similarities in purchasing behavior (Dennis and Behe, 2007; Roberts and Manolis, 2000). Age segmentation is effective because people of comparable ages have shared life experiences, including historical events, social norms, political influences, and educational standards (Roberts and Manolis, 2000). For example, a previous study found that as people age, material items become less important to them (Roberts and Manolis, 2000). As a result, people find greater enjoyment and fulfillment in other activities such as gardening and garden-like experiences as they age (Behe et al., 2003; Dennis and Behe, 2007).

Life experiences also shape how consumers view products and make purchasing decisions. Generation X and Generation Y are two distinct age groups that have been repeatedly studied and effectively targeted by other industries (Barrow, 1994; Littrell et al., 2005; Roberts and Manolis, 2000; Silvergleit, 2004) but, until recently, have been neglected by the floral industry. Generation X consists of 44 million people born between 1965 and 1976 (Dunn, 1993). Research suggests that consumers in this age group tend to value money, possessions, and the shopping experience more than older generations, potentially leading to greater credit card debt and personal bankruptcy (Dunn, 1993; Roberts and Manolis, 2000). Members of this age cohort are also characterized as educated, media-savvy, self-reliant, pragmatic, and often exhibit a distrust of uneducated people (Littrell et al., 2005). Compared with older generations, Generation X has had greater exposure to cable TV and the Internet (Bartlett, 1997; Roberts, 1998; Roberts and Manolis, 2000) resulting in their being receptive to marketing messages and yet often quite cynical and suspicious of them (Freeman, 1995; Roberts and Manolis, 2000).

Generation Y consists of 71 million people born between 1977 and 1994 (Morton, 2002; Paul, 2001). These individuals are thought to have distinct traits and spending behaviors that differ from previous generations (Maciejewski, 2004). For instance, Maciejewski (2004) found this group to be distrustful of political agendas and of the media as a result of their views being biased on important issues. Additionally, celebrities have less influence as a result of publicized scandals; as a result, this generation tends to have greater respect for parents and grandparents than celebrities. Another difference is that Generation $\mathrm{Y}$ is accustomed to having discretionary dollars to spend and therefore expects to have sufficient financial resources to maintain a certain standard of living. For example, in 1999, Generation Y spent \$153 billion and influenced their parents to spend an additional \$48 billion (Rushkopf, 2001). With so much spending power, this group is an attractive market segment and gaining 
insight as to their preferences greatly enhances an industry's ability to market to this group.

Over $\$ 100$ billion is typically spent each year in the United States on gifts (Parson, 2002), making the understanding of gift selection and purchasing decisions a necessary requisite for industries supplying gift-related products and services. Studies have shown that gift giving often symbolizes levels of trust, cooperation (Bolle, 2001), attractiveness, devotion, and the intensity of social relationships (Huang and $\mathrm{Yu}, 2000)$. In addition, gifts implicitly communicate the giver's intentions and attitudes about the gift and recipient (Burgoyne, 1999). Given the amount of money spent on gifts by U.S. consumers and that $75 \%$ to $80 \%$ of floral transactions $(\approx \$ 5$ million of industry revenues) are for gifts (IBISWorld Inc., 2010; Silvergleit, 2004), the present study was designed to explore the use of floral gifts among Generations $X$ and $Y$. This information could then be used by the floral industry to address the problem of the downward trend in floral sales (IBISWorld Inc., 2010; Silvergleit, 2004).

To optimize the use of fresh floral products as gifts, what are commonly referred to as the four Ps of marketing must be explored, including product, price, promotion and placement, because each plays a role in driving purchasing decisions (Kerin et al., 2009). The product is a good, service, or idea that satisfies the consumer's needs such as a bouquet or a florist's design and delivery services. The price is what is exchanged for the product and the promotion is used as a means of communication between the seller and buyer. Promotions include paid commercials, advertisements, Internet pop-up advertisements, and word of mouth. Placement is the means of getting the product to the consumer (Kerin et al., 2009) and can either be a physical location such as a retail store or it can be mental imagery such as an environmentally friendly company or product. This study explored the perceptions of Generations $\mathrm{X}$ and $\mathrm{Y}$ relative to product, price, promotion, and placement of floral products as gifts. The overall objective was to discover ways to assist the floral industry to improve sales and increase the use of floral products as gifts by Generations $\mathrm{X}$ and $\mathrm{Y}$ consumers by investigating their perception of and preferences relative to the 4 Ps of floral marketing. Specifically we: 1) explored Generations X and Y's positive or negative attitudes toward flowers as gifts; 2) explored differences in perceptions about price, product, place, and promotions among Generations $\mathrm{X}$ and $\mathrm{Y}$ to determine the best marketing techniques to reach them; and 3 ) determined what actions the floral industry can take to improve Generations $\mathrm{X}$ and Y's use of flowers as gifts.

Research results can be used by florists, floral producers, and other marketing intermediaries that sell fresh floral products to develop strategies for improving product marketability and enhancing consumer loyalty through positive experiences. This study also contributes to the literature regarding the decision-making processes of consumers in making floral purchases and their use of floral gifts compared with other competing gifts of similar prices.

\section{Materials and Methods}

Study site. The study was conducted on 18 Apr. and 25 Apr. 2009 at the University of Minnesota, and 26 June and 27 June 2009 at Michigan State University. There were 109 participants from Minneapolis and St. Paul, $\mathrm{MN}$, and 117 participants from Lansing and East Lansing, MI.

Participant recruitment. Participants were recruited through advertisements in local newspapers and Craigslist. Advertising exclusively on campus was avoided to encourage a wider demographic to participate. To mitigate selfselection bias in the advertisement, we did not mention that the study was about flowers as gifts. Instead, we specified that "In order to participate, you must have purchased gifts in the past year and have to be between ages 18 and 50 years old." The advertisements were placed in newspapers that are distributed to both metro and suburban areas. Participants selected for the study were placed in the following age groups for the study: 18 to 32 ("Generation Y") and 33 to 50 year olds ("Generation X"). Participants younger than age 18 years were not included in this study as a result of being minors and still being dependent on their guardians for financial support. We were specifically interested in studying individuals between the ages of 18 and 50 as a result of decreasing purchases in this age group. Fifty was set as the oldest age for our study because previous research has shown that people older than 50 years make the most floral purchases (Silvergleit, 2004). Surveys and focus groups were conducted with only persons present within the same age group.

Experiment set-up. Participants were brought into a closed room and asked not to communicate with other participants. They were given a clipboard, pencil, and folder containing a questionnaire, ID number, receipt, an introduction form, and Institutional Review Board consent form. Participants were identified by their ID number throughout the experiment. The moderator read through the consent form, introduction form, and instructions and answered questions. Participants were then asked to sign the consent form and proceed to complete a questionnaire.

Questionnaire. In the questionnaire (and subsequent focus group discussions), flowers were defined as cut flowers and blooming potted plants. Each questionnaire consisted of questions concerning purchasing behaviors, attitudes toward gifts, flowers as gifts, gift personality reflection, gift practicality, gifts chosen by occasion, and participants' sociodemographics.

To determine the structure and wording of questions in the questionnaire, a pilot study was conducted at the University of Minnesota. This study revealed that young consumers frequently used gift cards, food/candy, CD/ $\mathrm{DVD} /$ book, or wine as gifts. Based on these results, these specific items were included as gift alternatives for comparison purposes.
Questionnaires were approved by both university committees for the protection of human subjects.

Questions in the questionnaire (which were determined from the results of the pilot study) were focused around the 4 Ps of marketing. Questions about product included: How much do the following gifts (wine, cut flowers, $\mathrm{CD} / \mathrm{DVD} /$ book, gift cards, plants, and food/ candy) reflect your personality? How often do you purchase each of the gifts annually? What attributes are important to your purchasing decision (e.g., quality, care, price, aesthetics, packaging, design, meaning, fragrance, environmental attributes, etc.)?

Questions about promotions included: How often do you see the gifts being advertised? What actions or options would increase your likelihood of purchasing flowers as gifts (e.g., price options, exposure and information, sustainability, experience, uniqueness, packaging, and flower attributes, etc.)?

Questions about price included: What is your upper spending limit for different gifts for different occasions? How much is your upper spending limit for floral gifts for different occasions? Do you think the market prices of floral gifts are reasonable?

Questions about place included: How much do you agree with the following statements about floral gifts (e.g., "flowers symbolize love," "I enjoy receiving flowers," and so forth)? How easy are the gifts for you to purchase?

Focus groups. On completion of the questionnaire, participants were divided into smaller groups (eight to 12 people) to participate in a focus group discussion. Pre-determined questions were asked that provided participants an opportunity to elaborate on their thoughts about floral gifts and the floral industry. The focus group questions were determined by the results of the pilot study and formatted around the 4 Ps of marketing. For example, several product questions included: What aspects are you not satisfied with (quality, color, variety, smell, cost, location)? What would you suggest the industry does to improve floral gifts? What do you think about the services provided by the floral industry? What do you think about the longevity of flowers? What are ways the industry can improve your perception of floral longevity? What do you think about the current packaging options? How would you suggest florists improve current packaging options? What can the industry do to improve floral gifts in general?

At the end of the experiment, participants were given $\$ 40$ to compensate them for their time. Combined, 226 completed questionnaires were obtained from Minnesota and Michigan.

Econometric model. Many of the questions contained Likert scale options in which participants were asked to indicate their intensity of agreement. Because the Likert scale options are considered discrete variables instead of continuous variables, we needed to use discrete choice models to estimate the data. The opinion or attitudinal variables are ordinal discrete variables, so we used an 
ordered probit model, because in a survey that asks the respondents' opinions, the respondents' intensity of feelings is dependent on some measurable factors and some unobservable factors. In many situations, the respondents are given only a set number of possible answers, say five, to the question of $y$. Consumers choose the cell that most closely represents the intensity of response to the question. For example, for product $j$ 's price, consumer $i$ is asked to choose among the five choices on a Likert scale: very reasonable $\left(y_{i j}=1\right)$, reasonable $\left(y_{i j}=2\right)$, neutral $\left(y_{i j}=3\right)$, unreasonable $\left(y_{i j}=4\right)$, or very unreasonable $\left(y_{i j}=5\right)$. The consumers' choice of the five categories is dependent on an underlying utility/satisfaction function from certain products' attributes. Suppose $U_{i j}$ is the utility/ satisfaction that consumer $i$ derives from $j$ and $U_{i j}$ can be expressed as follows:

$$
\begin{aligned}
U_{i j}= & \alpha_{j}+\beta_{1} \text { agegroup }_{i}+\beta_{2} \text { education }_{i} \\
& +\beta_{3} \text { gender }_{\mathrm{i}}+\beta_{4} \text { marriage }_{i} \\
& +\beta_{5} \text { household }_{i}+\beta_{6} \text { income }_{i} \\
& +\varepsilon_{\mathrm{ij}} ; i=1, \ldots, 226(n) ; j=\text { wine }, \\
& \text { cut flowers }, \text { book, gift card }, \\
& \text { food }, \text { and plants. }
\end{aligned}
$$

where $\alpha_{j}$ is the design matrix, which is a row vector of the $i$ th consumer's characteristics, which include sociodemographics and product quality attributes; $\alpha_{j}$ is the dependent variable (the selected gift) coefficient that participants selected; $\beta_{j}$ is the sociodemographic coefficient associated with $\alpha_{j}$ indicating the effect of $\beta_{j}$ on $\alpha_{j}$; and $\varepsilon_{i j}$ is the residual error term that is not captured by design matrix $\alpha_{i}$, which is assumed to follow a normal distribution with mean zero and SD $\sigma_{\varepsilon}$. There are $226(n)$ consumers and six $(J)$ products.

$U_{i j}$ cannot be observed. What we observe is the $i$ th consumer's choice, which is denoted as $y_{i j}$.

$$
\begin{array}{cccc}
y_{i j}= & \text { if } & U_{i j} \leq u_{0 j} \\
y_{i j}=1 & \text { if } & u_{0 j}<U_{i j} \leq u_{1 j} \\
y_{i j}=2 & \text { if } & u_{1 j}<U_{i j} \leq u_{2 j} \\
\vdots & & \\
y_{i j}=K & \text { if } & u_{k-1, j} \leq U_{i j}
\end{array}
$$

The structure of Eq. (2) is a form of censoring for $i=1, \cdots, n ; j=1, \cdots J$. The $u$ s are unknown parameters that can be estimated; consumer $i$ has $K$ choices. $\varepsilon_{i j}$ is assumed to be normally distributed across observations. In consequence, for $i=1, \cdots, n ; j=1, \cdots, J$ we have the following probabilities:

$$
\begin{aligned}
& \operatorname{Prob}\left(y_{i j}=1\right)=\Phi\left(u_{l j}-X_{i} \beta_{j}\right) \\
& \operatorname{Prob}\left(y_{i j}=2\right)=\Phi\left(u_{2 j}-X_{i} \beta_{j}\right)-\Phi\left(u_{l j}-X_{i} \beta_{j}\right) \\
& \operatorname{Prob}\left(y_{i j}=3\right)=\Phi\left(u_{3 j}-X_{i} \beta_{j}\right)-\Phi\left(u_{2 j}-X_{i} \beta_{j}\right)
\end{aligned}
$$

$\operatorname{Prob}\left(y_{i j}=k\right)=1-\Phi\left(u_{k, j}-X_{i} \beta_{j}\right)$

where $\Phi(\cdot)$ is the cumulative distribution function for standard normal distribution. Analysis of variance (ANOVA) was also used to determine significance of data. Data analysis was performed in the SAS (SAS Institute, Inc., Cary, NC) and STATA (College Station, TX) software packages.

\section{Results and Discussion}

Sample distribution. The complete summary statistics are shown in Table 1. Approximately $39 \%$ of the participants in the study were in the Generation Y age cohort and 61\% were in the Generation $X$ cohort. Participants in the Generation Y group averaged 24 years of age and participants in the Generation $\mathrm{X}$ group averaged 43 years of age. On average, participants in both generations had completed "some college," indicating similar education level. Both groups consisted of a greater percentage of females, which was desirable because previous research has shown females purchase more floral products than males (Burke, 2007; Yue and Behe, 2008). Among those in the Generation Y group, 57\% were married or in a relationship as were $67 \%$ of Generation X participants (Table 1). Members of the Generation $\mathrm{Y}$ groups averaged 2.4 people per household and members of the Generation X groups had 3.0 people per household. As for household income, Generation Y participants averaged $\$ 42,240$ per year and Generation $X$ averaged $\$ 61,640$ per year (Table 1). The household income results indicate the longer an individual is in the work force, the greater his or her household income is, resulting in the older generation having higher household incomes.

Attitude toward and spending limit on floral gifts. ANOVA was used to compare differences between Generations X and Y's level of agreement with statements about

consumers' attitudes toward floral gifts. Attitude was used to help define consumers' mental imagery of floral gifts. Both generations agreed with the following statements, but Generation $\mathrm{X}$ participants had a slightly higher level of agreement with "fresh flowers are good gifts for cheering someone up" than Generation Y members $(P=0.0036)$. Similarly, Generation $\mathrm{X}$ members had a higher level of agreement with the following statements "flowers remind me of a special memory" $(P=0.0138)$, "flowers are the best way to put a smile on someone's face" ( $P \leq 0.0001)$, "flowers are a way to convey a number of messages in a unique way" $(P=0.0015)$, "I enjoy receiving flowers" $(P=$ $0.0338)$, "flowers are safer gifts than others" $(P=0.0025)$, and "it is hard to go wrong with flowers as gifts" ( $P=0.0073)$.

Additional findings revealed Generation Y participants had a higher level of agreement with "flowers are a perishable luxury" than Generation X $(P=0.0745)$. Similarly, Generation $\mathrm{Y}$ members had a higher level of agreement with the following: "I am reluctant to spend money on something that will only last a few days" $(P=0.0769)$, "my friends do not like to receive flowers as gifts compared with other products" ( $P \leq 0.0001)$, "there are many other choices of gifts that are more appropriate than flowers" $(P=0.0014)$, and "I

\begin{tabular}{|c|c|c|c|c|}
\hline Variable & Description of variables & Generation & Mean & SD \\
\hline \multirow[t]{2}{*}{ Age } & Age of participants in years & $\mathrm{Y}$ & 24.39 & 4.38 \\
\hline & & $\mathrm{X}$ & 42.90 & 5.17 \\
\hline \multirow[t]{8}{*}{ Education } & Highest level of education & $\mathrm{Y}$ & 3.67 & 1.19 \\
\hline & participants completed & & & \\
\hline & $1=$ Some high school or less & & & \\
\hline & $2=$ High school diploma & & & \\
\hline & $3=$ Some college & $\mathrm{X}$ & 3.79 & 1.18 \\
\hline & $4=$ College diploma & & & \\
\hline & $5=$ Some graduate school & & & \\
\hline & $6=$ Graduate degree & & & \\
\hline \multirow[t]{3}{*}{ Gender } & Gender of participant & $\mathrm{Y}$ & 0.45 & 0.50 \\
\hline & $1=$ male $(36 \%$ of total $)$ & $\mathrm{X}$ & 0.30 & 0.46 \\
\hline & $0=$ female $(64 \%$ of total $)$ & & & \\
\hline \multirow[t]{3}{*}{ Relationship } & Marital status of participant & $\mathrm{Y}$ & 0.57 & 0.50 \\
\hline & $1=$ married $/$ in a relationship & $\mathrm{X}$ & 0.67 & 0.47 \\
\hline & $0=$ no relationship & & & \\
\hline \multirow[t]{3}{*}{ Household } & Number of people in household & $\mathrm{Y}$ & 2.36 & 1.49 \\
\hline & (including participant, spouse, & $\mathrm{X}$ & 3.03 & 1.39 \\
\hline & $\begin{array}{l}\text { and any dependents but excluding } \\
\text { roommates) }\end{array}$ & & & \\
\hline \multirow{2}{*}{$\begin{array}{l}\text { Household } \\
\text { income }\end{array}$} & Annual income earned in 2008 by & $\mathrm{Y}$ & $\$ 42,239.58$ & $\$ 36,077.78$ \\
\hline & $\begin{array}{l}\text { people in participants' households } \\
\text { (with "household" defined above) }\end{array}$ & $\mathrm{X}$ & $\$ 61,640.63$ & $\$ 34,556.85$ \\
\hline
\end{tabular}
don't see much advertisement about flowers as gifts in the media" $(P=0.0029)$. As a whole, Generation X members had a more positive position toward flowers as gifts, whereas Generation Y members had a more negative position.

The Generation Y market is underdeveloped in the floral industry (American Floral Endowment, 2008). Perhaps by increasing the number of promotions that demonstrates

Table 1. Summary statistics of the sample of 216 respondents who participated in floral-related focus group experiments conducted in Michigan and Minnesota in 2009. 
the positive attributes and trendiness of floral gifts, young consumers will be reassured, educated, and more confident in using floral gifts. In the past, advertising has been useful in promoting products in a mature market (Kerin et al., 2009). A new marketing message that flowers are peer-safe, trendy, and appropriate gifts for everyone could be used to overcome Generation Y's “my peers don't like receiving flowers" position. One way suggested by focus group participants to improve the image positioning of floral products is through increasing the longevity of flowers by supplying flower preservatives, drying kits, and storage items (bookmarks, cards, etc.). Dyed flowers and gimmicks should be avoided because Generation $\mathrm{Y}$ focus group participants perceived them as cheapening the gift. Focus group participants also felt the industry can suggest pairings with companion products Generation Y participants appreciate to increase individuality in floral gifts or florists can partner with other gift stores that are perceived as trendy to better attract young consumers.

Pairing or bundling of products has been shown to improve consumers' perceived value resulting in a greater willingness to pay for those items (Nagle et al., 2009). However, consumers are also concerned with price. To keep prices reasonable, focus group participants felt that having a discount for paired items would improve their likelihood of purchasing them. Florists can do this by adding elements that improve the visual appeal of the gift without increasing the price, thereby increasing their appeal to consumers who are shopping with a limited budget.

Spending limits were investigated to examine consumer perceptions on floral gift prices. On average, the upper spending limit on gifts and floral gifts was the highest for birthday occasions with Generation Y spending the most on birthday gifts in general and Generation $\mathrm{X}$ spending the most on floral birthday gifts (Figs. 1 and 2). The upper spending limit on floral gifts, as shown in Figure 2, was frequently lower than the spending limits on gifts in general (Fig. 1). Overall, Generation Y participants spent less on floral gifts. Focus group discussion results found Generation Y participants preferred more practical, longlasting gifts that reflect their sentiments and they do not like spending money on perishable luxury items.

When asked about improving price, focus group participants offered several ideas. With spending limits being higher for gifts in general than flowers, pairing them together has the potential to increase overall spending on floral gifts. Additionally, focus group participants mentioned being willing to spend more for unique or trendy arrangements, leading to the conclusion that by putting unique flowers into arrangements, consumers will rationalize spending more money to get what they want and are interested in. Moreover, because participants indicated they were more willing to spend money on birthday gifts than on other noncalendar occasions, as shown in Figure 1, florists would be well served to promote floral arrangements as trendy birthday gifts. Further-

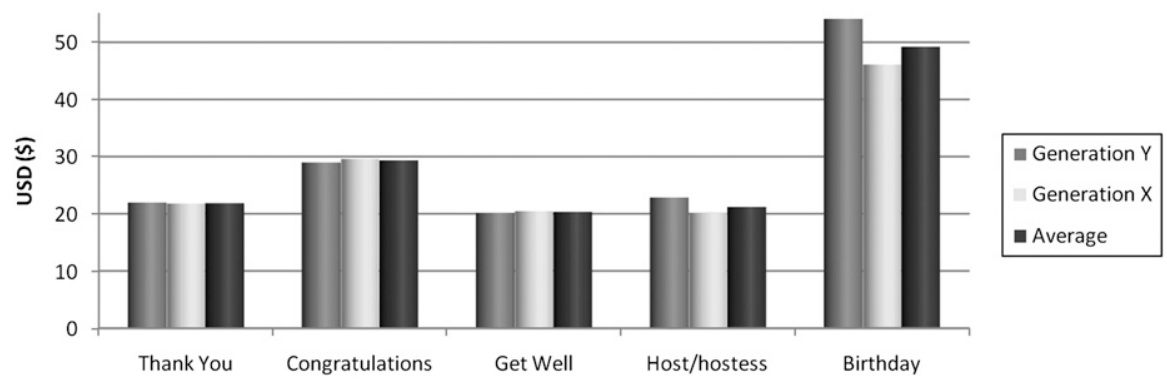

Fig. 1. Upper spending limit on gifts by occasion.

How much do you feel is your upper limit to spend on floral gifts for the following occasions?

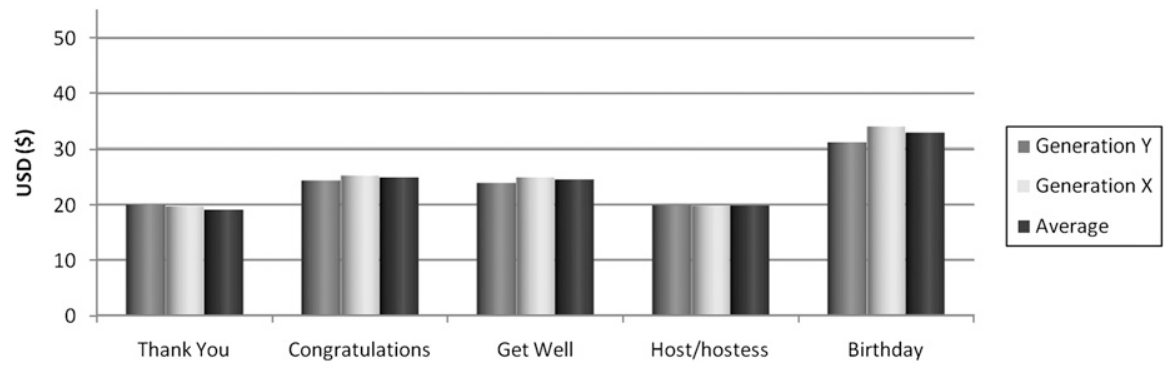

Fig. 2. Upper spending limit on flowers by occasion.

more, focus group participants felt having smaller and less expensive arrangements of a similar trendy, unique style would increase selections within customers' budget limits and thus improve customer satisfaction.

Flower purchasing frequency. To better understand the intensity of consumers interactions with floral products, floral purchasing frequency was investigated. In Generation Y, $58 \%$ purchased flowers one to three times annually, 23\% purchased four to six times, $9 \%$ seven to nine times, $4 \%$ bought flowers more than 10 times, and $6 \%$ never bought flowers, as shown in Table 2. In Generation $\mathrm{X}, 31 \%$ purchased flowers one to three times annually, $32 \%$ purchased four to six times, $21 \%$ purchased seven to nine times, $12 \%$ bought flowers 10 times or more annually, and 4\% never purchased flowers (Table 2). The results of the quantitative analysis showed a strong positive correlation between purchase frequency and age with an increase in the frequency of floral purchases as participants aged. Previous studies suggest this relationship is the result of the decreased importance of material items as a person ages (Roberts and Manolis, 2000). Less concern with material items may result in greater enjoyment of other involvements and activities such as gardening and garden-like experiences including the enjoyment of floral gifts (Behe et al., 2003; Dennis and Behe, 2007). Focus group participants also felt that as they aged, there were more opportunities when giving floral gifts were appropriate (e.g., get well and funeral occasions). Promoting and educating consumers
Table 2. Annual flower purchasing frequency by Generations $\mathrm{X}$ and $\mathrm{Y}$.

\begin{tabular}{lcc}
\hline Frequency & Generation $\mathrm{Y}$ & Generation $\mathrm{X}$ \\
\hline $1-3$ times & $58 \%$ & $31 \%$ \\
$4-6$ times & $23 \%$ & $32 \%$ \\
$7-9$ times & $9 \%$ & $21 \%$ \\
$10+$ times & $4 \%$ & $12 \%$ \\
Never & $6 \%$ & $4 \%$ \\
\hline
\end{tabular}

about floral gifts being great gifts for all occasions and reasons has potential to improve sales.

Personality reflection. Gift personality reflection also gives insights to consumers' perceptions of floral products. Consumers often want to purchase and give items that are representative of their personalities (Schiffman and Kanuk, 2007). Furthermore, in the pilot study, we found that consumers liked to purchase products that reflect their personalities, so in the questionnaire, we asked participants how much the different gifts reflected their personalities. In the ordered probit model, the dependent variable was how much they thought the products reflected their personality and the independent variables were gifts, age, education, gender, relationship, household size, and income. The estimation results revealed that Generation Y participants felt flowers did not reflect their personalities as much as wine (Table 3). Conversely, Generation X participants felt flowers reflected their personalities more than wine. However, for Generation Y participants, coefficients for the $\mathrm{CD} / \mathrm{DVD} /$ book category were significantly higher than Generation $\mathrm{X}$ members, indicating that Generation $\mathrm{Y}$ 
felt these gifts reflected their personalities the best out of all the gift options among all of the generations studied (Table 3).

Generation $\mathrm{X}$ focus group participants mentioned their liking blooming plants as a result of greater longevity, so florists should continue to supply high-quality potted flowering plants to keep this group loyal. However, Generation Y focus group participants were less interested in flowering plants as a result of the perceived increase in responsibility; that is, the receiver has to take care of the plant or feel guilty if it dies. Interestingly, these individuals prefer cut flowers to flowering plants. Focus group results suggest that the industry can develop unique cut flower arrangements to attract this group and add pairings of companion products to improve gift personality reflection. The younger generations desire to express themselves while giving the receiver a nice gift. Therefore, by improving the uniqueness and available pairings, floral gifts will be perceived to be trendier. Additionally, breeding and promoting lowermaintenance plants (with easy care instructions) can inspire the younger generations to try them by making the experience a positive and educational one.

Perception of market price. In the pilot study, we found that younger consumers did not buy flowers because they thought flower prices were not as reasonable as those of competing products. In the questionnaire, we asked participants how reasonable they felt the market prices were for different gift items to further understand consumers' perceptions of price. Ordered probit analysis was again used to analyze participants' perception of the market price of different gifts. In this ordered probit model, the dependent variable was participants' perception of reasonableness of the market price and the independent variables were the gifts, age, education, gender, relationship, household size and income. The results are shown in Table 4 with wine being used as the base for the estimation. A smaller coefficient for the product indicates perceived market prices to be more reasonable and a larger coefficient for the product indicates perceived market prices to be less reasonable compared with wine. For Generation $\mathrm{Y}$, the $\mathrm{CD} / \mathrm{DVD} /$ book category had the highest coefficient at 0.75 followed by flowers at 0.60 , food/candy at -0.06 , and gift cards at -0.59 with all being significant compared with wine, except for food/candy (Table 4). As previously mentioned in the Generation $Y$ personality reflection, these younger consumers placed cut flowers fourth behind CD/DVD/ book, gift cards, and food/candy (Table 3), which combined with high market price decreases the gift's value for this generation. For Generation X, flowers had the highest coefficient with 0.12 followed by $\mathrm{CD} / \mathrm{DVD} /$ book at 0.08 , food/candy at -0.35 , and gift cards at -1.03 with only gift cards and food/ candy being significantly different from wine (Table 4). Overall, flower and $\mathrm{CD} /$ DVD/book gifts' prices were perceived to be more unreasonable than wine for both generations.

Table 3. Respondents in each age segment indicating how much the listed gifts reflect their personalities as gift givers-estimation results of ordered probit model (greater coefficient value $=$ reflects personality).

\begin{tabular}{|c|c|c|c|c|}
\hline \multirow[b]{2}{*}{ Variable $\left(\alpha_{j}\right)$} & \multicolumn{2}{|c|}{ Generation Y $(\mathrm{n}=88)$} & \multicolumn{2}{|c|}{ Generation X $(n=138)$} \\
\hline & Coefficient & SE & Coefficient & SE \\
\hline Flowers & -0.11 & 0.13 & $0.56^{* * *}$ & 0.12 \\
\hline CD/DVD/book & $0.49 * * * \mathrm{z}$ & 0.16 & $0.42 * * *$ & 0.14 \\
\hline Gift card & 0.19 & 0.15 & $0.62 * * *$ & 0.14 \\
\hline Food/candy & $0.17 * * *$ & 0.15 & $0.44 * * *$ & 0.14 \\
\hline Wine & Base & Base & Base & Base \\
\hline \multicolumn{5}{|c|}{ Sociodemographic variable $\left(\beta_{j}\right)$} \\
\hline Education & 0.05 & 0.05 & 0.01 & 0.04 \\
\hline Gender & -0.04 & 0.04 & $-0.10 * *$ & 0.04 \\
\hline Marriage & -0.02 & 0.05 & -0.05 & 0.05 \\
\hline Household size & $0.12 * *$ & 0.05 & 0.00 & 0.05 \\
\hline Income & 0.01 & 0.05 & -0.06 & 0.05 \\
\hline
\end{tabular}

z*,**,***Significant at $P \leq 0.10,0.05$, or 0.01 , respectively.

Table 4. Respondents in Generations $\mathrm{X}$ and $\mathrm{Y}$ indicating how reasonable they think the market price is for the listed items - estimation results of ordered probit model (greater coefficient value $=$ more unreasonable market price).

\begin{tabular}{|c|c|c|c|c|}
\hline \multirow[b]{2}{*}{ Variable $\left(\alpha_{j}\right)$} & \multicolumn{2}{|c|}{ Generation Y } & \multicolumn{2}{|c|}{ Generation X } \\
\hline & Coefficient & SE & Coefficient & $\mathrm{SE}$ \\
\hline Flowers & $0.60 * * * \mathrm{z}$ & 0.16 & 0.12 & 0.13 \\
\hline CD/DVD/book & $0.75 * * *$ & 0.16 & 0.08 & 0.13 \\
\hline Gift card & $-0.59 * * *$ & 0.16 & $-1.03 * * *$ & 0.14 \\
\hline Food/candy & -0.06 & 0.16 & $-0.35 * *$ & 0.14 \\
\hline Wine & Base & Base & Base & Base \\
\hline \multicolumn{5}{|c|}{ Sociodemographic variable $\left(\beta_{j}\right)$} \\
\hline Education & -0.07 & 0.05 & $0.09 * *$ & 0.05 \\
\hline Gender & -0.03 & 0.05 & $0.10 * *$ & 0.05 \\
\hline Marriage & 0.08 & 0.05 & -0.06 & 0.05 \\
\hline Household size & -0.10 & 0.06 & 0.05 & 0.05 \\
\hline Income & 0.00 & 0.06 & 0.05 & 0.06 \\
\hline
\end{tabular}

z* $* *, * * *$ Significant at $P \leq 0.10,0.05$, or 0.01 , respectively.

Focus group participants had several suggestions for improving perceptions of value. First, they felt the industry can create pairings to improve value by looking at other gifts each group likes to give. For example, for Generation $\mathrm{Y}$, pairing floral gifts with $\mathrm{CD} / \mathrm{DVD} /$ books or gift cards could increase perceived value. Generation X preferred pairing floral gifts with gift cards. Additionally, florists could partner with other gift stores to place their products within the store and/or offer coupons to increase the ease of pairing. Also, the industry can offer bouquets of similar design but with different sizes and offer them at different price points so consumers can still get the design they like but at a price they deem affordable.

Perception of ease of purchase. In the pilot study, we found that consumers felt flowers were more difficult to purchase than competing gift products. To better understand this positioning issue, in the questionnaire we asked participants how easy it was for them to purchase different gift items. Ordered probit analysis was also used to analyze their perception regarding the ease of purchase. In this ordered probit model, the dependent variable was the perception of ease of purchase and the independent variables were the gifts, age, education, gender, relationship, household size, and income. Wine was used as the base for estimation. A smaller coefficient of a product indicates that consumers perceive the product to be easier to purchase and a larger coefficient of a product indicates that consumers perceive the product to be more difficult to purchase compared with wine. Generation Y participants felt flowers were the most difficult to obtain when compared with wine (Table 5). None of the other gifts were as difficult to obtain as wine with the CD/DVD/book category at -0.27 , food $/$ candy at -0.64 , and then gift cards at -1.28 (Table 5). All of these results were significantly different from wine except flowers. For Generation Y participants, the average age was 24 years old; however, there were some participants under the legal drinking age of 21 , which could lead to wine being more difficult to obtain than the other gift items. Generation X members felt that $\mathrm{CD}$ / DVD/books were the most difficult to purchase compared with wine (Table 5). All of the other gifts were easier to purchase than wine with flowers at -0.31 , food/candy at -0.57 , and gift cards at -1.18 (Table 5 ). The perception of ease of purchase estimation results indicate that as people age, they feel it is easier to purchase flowers as gifts and more difficult to purchase $\mathrm{CD} / \mathrm{DVD} /$ books as gifts. However, for the younger generations, pairing flowers with $\mathrm{CD} / \mathrm{DVD} /$ books or gift cards may increase use of floral gifts.

When asked about improving ease of purchase, focus group participants had several suggestions. First, they felt the industry should launch an educational marketing campaign to increase awareness and knowledge 
of floral gifts and locations of florists. By promoting the product and where it is located, consumers will feel more confident in their abilities to find and select the right gift. Also, focus group participants felt florists should display clear signage and create an inviting store exterior to draw in more foot traffic and increase sales. Furthermore, focus group participants added that florists could host events that the different age groups are interested in such as live music and flower design classes to attract more foot traffic.

Frequency of advertising. In the pilot study, we found that consumers did not frequently view advertisements for floral gifts. To explore promotional concerns, in the questionnaire, participants were asked how often they viewed advertising for different gifts. Advertising is an important part of firm-level promotional strategies and has a positive correlation to improved sales and brand equity (Kerin et al., 2009). To explore gift advertising awareness, participants were asked how frequently they viewed advertising for gifts and ordered probit analysis was used to analyze the advertising data with wine being the base for estimation. In this ordered probit model, the dependent variable was the perceived frequency of advertising and the independent variables were the gifts, age, education, gender, relationship, household size, and income. A smaller coefficient of a product indicates consumers see advertisements of the product more frequently and a larger coefficient of a product indicates consumers see the product advertisement less frequently compared with wine. For Generation $\mathrm{Y}$, the coefficient of flowers was 0.10 followed by gift cards at $-0.76, \mathrm{CD} / \mathrm{DVD} /$ book at -1.55 , and food/candy at -1.70 when compared with wine (Table 6). All were significant except for flowers. For Generation X, the coefficient of flowers was 0.20 followed by gift cards at $-0.59, \mathrm{CD} / \mathrm{DVD} /$ books at -0.86 , and food/candy at -1.15 compared with wine (Table 6). Again, all results were significant except for flowers. All participants agreed that they saw advertisements for flowers the least when compared with wine, which accentuates the earlier finding of younger consumers finding flowers more difficult to purchase compared with other gifts (Table 5). These results also help explain the findings that Generations $\mathrm{X}$ and $\mathrm{Y}$ do not use floral gifts frequently (Table 2). Conversely, food/candy advertisements were seen the most frequently compared with wine, resulting in increased ease of purchase (Table 5).

Generation Y members observed significantly more $\mathrm{CD} / \mathrm{DVD} /$ book advertisements than Generations X members, meaning Generation $\mathrm{Y}$ participants were more aware of where to purchase $\mathrm{CD} / \mathrm{DVD} /$ books and therefore used them as gifts more frequently (Table 5). Focus group discussions indicate that Generation Y consumers felt CD/DVD/book gifts were brought to their attention more through advertising resulting in these items being purchased more frequently than other items. This group also felt flowers were not advertised as much, resulting in less frequent purchases. Generation X viewed more floral advertise-

Table 5. Generations $\mathrm{X}$ and $\mathrm{Y}$ respondents indicating how easy it was for them to purchase different gift items - estimation results of ordered probit model (greater coefficient value $=$ more difficult).

\begin{tabular}{|c|c|c|c|c|}
\hline \multirow[b]{2}{*}{ Variable $\left(\alpha_{j}\right)$} & \multicolumn{2}{|c|}{ Generation $\mathrm{Y}$} & \multicolumn{2}{|c|}{ Generation $\mathrm{X}$} \\
\hline & Coefficient & $\mathrm{SE}$ & Coefficient & $\mathrm{SE}$ \\
\hline Flowers & -0.08 & 0.15 & $-0.31^{* *}$ & 0.14 \\
\hline CD/DVD/book & $-0.27^{* z}$ & 0.16 & -0.10 & 0.14 \\
\hline Gift card & $-1.28 * * *$ & 0.18 & $-1.18 * * *$ & 0.15 \\
\hline Food/candy & $-0.64 * * *$ & 0.16 & $-0.57 * * *$ & 0.14 \\
\hline Wine & Base & Base & Base & Base \\
\hline \multicolumn{5}{|c|}{ Sociodemographic variable $\left(\beta_{j}\right)$} \\
\hline Education & -0.04 & 0.06 & -0.03 & 0.05 \\
\hline Gender & $0.14 * * *$ & 0.05 & 0.03 & 0.05 \\
\hline Marriage & 0.09 & 0.05 & 0.05 & 0.05 \\
\hline Household size & $0.18 * * *$ & 0.06 & $-0.14 * *$ & 0.05 \\
\hline Income & $-0.15 * *$ & 0.06 & 0.08 & 0.06 \\
\hline
\end{tabular}

Table 6. Frequency of advertisements that respondents saw for different gift items - estimation results of ordered probit model (greater coefficient value = less frequently viewed).

\begin{tabular}{|c|c|c|c|c|}
\hline \multirow[b]{2}{*}{ Variable $\left(\alpha_{j}\right)$} & \multicolumn{2}{|c|}{ Generation Y } & \multicolumn{2}{|c|}{ Generation $\mathrm{X}$} \\
\hline & Coefficient & SE & Coefficient & SE \\
\hline Flowers & 0.10 & 0.15 & 0.20 & 0.13 \\
\hline CD/DVD/book & $-1.55 * * * z$ & 0.17 & $-0.86^{* * *}$ & 0.14 \\
\hline Gift card & $-0.76 * * *$ & 0.15 & $-0.59 * * *$ & 0.13 \\
\hline Food/candy & $-1.70 * * *$ & 0.17 & $-1.15 * * *$ & 0.14 \\
\hline Wine & Base & Base & Base & Base \\
\hline
\end{tabular}

$\underline{\text { Sociodemographic variable }\left(\beta_{j}\right)}$

\begin{tabular}{|c|c|c|c|c|}
\hline Education & -0.05 & 0.06 & 0.04 & 0.05 \\
\hline Gender & -0.03 & 0.05 & 0.00 & 0.05 \\
\hline Marriage & 0.05 & 0.05 & 0.02 & 0.05 \\
\hline Household size & -0.07 & 0.06 & 0.07 & 0.05 \\
\hline Income & -0.02 & 0.06 & $0.14 * *$ & 0.06 \\
\hline
\end{tabular}

ments and less CD/DVD/book advertisements resulting in greater confidence in locating and choosing the correct floral gift and less confidence in choosing a CD/DVD/book gift. These results show advertising for floral products needs to be restructured toward specific age groups to improve the advertisement's visibility and effectiveness.

Focus group participants mentioned many ways of improving floral gift advertisements. Many focus group participants mentioned funny, clever advertisements with goodlooking people were easiest to remember. TV and Internet ads are the most often viewed but not necessarily the most often remembered. A little creativity goes a long way, they said. Many focus group participants felt that by running advertising campaigns year-round that are structured to be funny, professional, and original, more people will remember the company/product, potentially increasing sales. Many people are more attentive to reputation and buzz, so to develop positive word-ofmouth advertising, florists can offer excellent services, high-quality products, and product guarantees. Florists can offer product warranties to improve customer confidence. The industry can develop professional advertisements and in-store displays with information available on creative pairings and provide more information on floral symbolism. Stores can promote sales and discount programs and showcase unique, fun flowers that are available at the shop. To reach Generation Y, the industry can advertise in areas and stores they frequently visit as well as on Facebook, YouTube, and Twitter. Statistics support using social media to reach young consumers. The majority of Facebook users $(63.1 \%)$ are younger than 34 years old (Gonzalez, 2010), 88\% of Twitter users are younger than age 34 years old (Cheng and Evans, 2009), and 52\% of YouTube users are younger than 34 years old (YouTube, 2010).

Actions that increase likelihood of purchasing floral products. To further explore the best points to highlight through promotional efforts, actions that increase likelihood of purchase were examined. Many of the items mentioned also pertained to product and price. Participants were asked to rate different options on whether implementing them would increase their likelihood of purchasing floral products. Of 28 original options, participants rated 19 greater than a score of 4 (on a 1 to 7 Likert scale), indicating the actions would improve their likelihood of purchase, as shown in Figure 3. Options closer to a rating of 7 have greater impact on purchasing decisions than those closer to zero.

The results show that special discounts and sales, greater longevity, more price ranges, and unique flowers/arrangements were the most influential options (Fig. 3). Other options that had some impact included flowers that were interesting shapes, trendy/fashionable, customized, uniquely packaged, paired (with other 


\section{Actions or options that would increase your likelihood of purchasing flowers as gifts. (1=Extremely unlikely, 7=Extremely likely)}

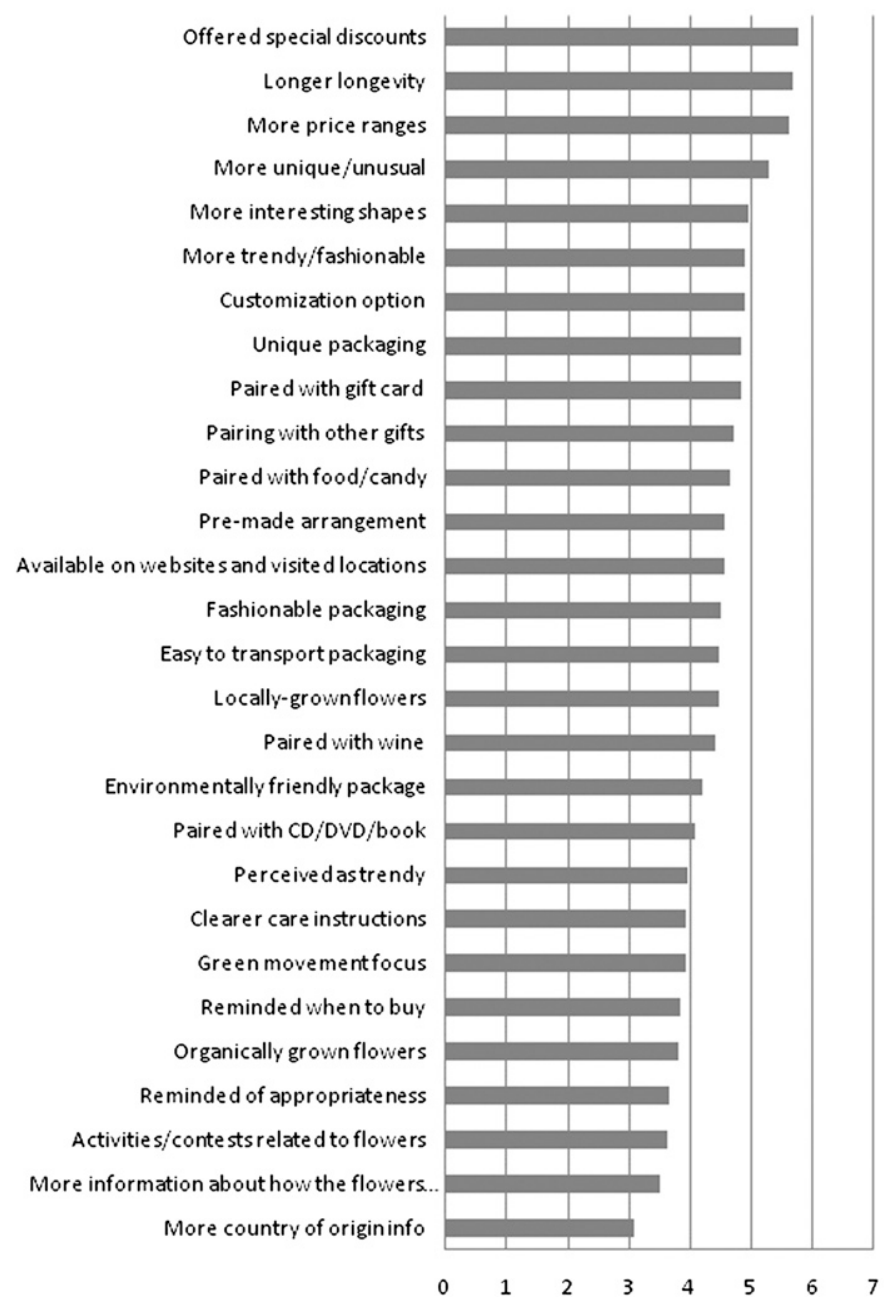

Fig. 3. Which of the following actions or options would increase participants' likelihood of purchasing flowers as gifts ( $1=$ extremely unlikely, $7=$ extremely likely $)$.

gifts, gift cards, and food/candy), in pre-made bouquets, or readily availability at often visited locations/web sites (Fig. 3). Other important options were fashionable/transportable packaging, locally grown, additional pairings (wine and $\mathrm{CD} / \mathrm{DVD} /$ books), and environmentally friendly packaging (Fig. 3). Focus group results showed that the packaging should not detract from fresh flowers or cheapen the gift. Focus group participants felt pairings improved gift longevity, practicality, and uniqueness. Participants from Generation Y's focus group discussion felt pre-made arrangements or bouquets were the best option as a result of their perceived lack of giver creativity and knowledge about what flowers go best together. Similarly, this focus group felt having flowers available where they spend time and advertisements on social media would improve sales. Actions that were less influential on purchasing decisions are also listed in Figure 3.

Overall, participants were more aware of price, longevity, uniqueness, bloom shapes, and customization in floral products when making purchasing decisions. However, they were also aware of packaging (aesthetics, transportability, uniqueness), trendiness, pairings, availability, pre-made options, and whether the flowers were locally grown when making decisions. As a result, each of these items represents a potential area for improvement among members of the floral industry. Advertising sales and developing fun discount/ loyalty programs could attract new customers to try floral products and enter floral stores. Focus group participants felt the industry should develop an expected longevity chart showing different flowers' expected longevity to alleviate post-purchase dissatisfaction by increasing knowledge about reasonable expectations. Additionally, focus group participants felt the industry can develop a line of locally produced flowers so customers feel good about helping the local economy.

\section{Conclusions}

To assist the floral industry in rejuvenating demand for floral products, this article presents Generations $\mathrm{X}$ and $\mathrm{Y}$ consumers' views on floral products, price, promotions, and positioning. Specific areas studied included: attitudes toward floral products, spending limits on gifts and floral gifts, purchasing frequency of floral products, consumer flower knowledge, gift personality reflection, perceived market price, ease of gift purchase, gift advertising frequency, and characteristics consumers view as important when making purchasing decisions. Quantitative (questionnaire) and qualitative (focus group) data were collected to investigate differences between generations in gift choice and preferences.

Based on participants' agreement with different attitudes toward flowers and the focus group results, our study's results for product, position, and price indicate that flowers are special gifts for both generations with Generation Y having some reservations about recipient enjoyment and the cost of the gift. Generation Y focus group participants felt floral gifts had some social and economic barriers making them less desirable gifts. Educational-related marketing could aid in overcoming some reservations and increase use of floral gifts, thereby increasing overall floral sales.

From the gifting occasion frequency and expenditure results, it is apparent that great potential exists to position flowers as a safe (well-received) yet surprising birthday gift. Most participants spent the most on birthday gifts making this event an ideal target to increase sales across the calendar year. Focus group participants felt useful or needed gifts were more appropriate for birthday occasions, so any marketing campaign that emphasized this appropriateness for flowers could assist in decreasing hesitancy over floral birthday gifts and improve consumer awareness of the appropriateness of floral birthday gifts.

The results for personality reflection of different gifts, perceptions of market price, ease of purchase, and advertising indicate that Generation $Y$ consumers view flowers as high-priced, difficult to obtain, and not frequently advertised, resulting in their purchasing floral products less frequently than other gift items. Flowers are considered expensive but do not reflect the gift giver's personality as well as other gifts, which decreases their gift value in Generation Y gift givers' minds. For the CD/DVD/book category, despite the high perceived price, these gifts are perceived as reflecting the gift giver's personality the best for this generation. Generation X placed more value on flowers indicating greater enjoyment and confidence in choosing the correct floral gift. Overall, participants noticed prices but were willing to pay more for gifts that reflected their personality and knowledge of the receivers' preferences. These findings are consistent with earlier studies (Robben and Verhallen, 1994; Teigen et al., 2005). Restructuring memorable advertising campaigns toward specific age groups using social media Generations X and $\mathrm{Y}$ are often exposed to can bring floral gifts into their scope when searching for gifts. 
Additionally, several other positioning actions can be implemented to improve the likelihood of using floral gifts such as sales promotions, proven longevity, more price point offerings, and more unique/trendy flowers and packaging. Combining these elements with pairings with other products has potential to improve perceived value and demand for floral gifts.

Based on positive results from the product, price, promotion, and positioning questionnaire questions (attitude toward flowers, purchasing frequency, personality reflection, perception of market price, ease of purchase, and advertising frequency questions) as well as focus group discussion results, it becomes apparent that Generation X has a more positive attitude about floral gifts when compared with Generation Y. By tailoring the marketing mixes toward each age segment, floral products can potentially be shifted from the mature stage to the growth stage resulting in greater demand, sales, and profits.

It should be noted that our sample frame was from Minnesota and Michigan, which may not be representative of Generations X and $\mathrm{Y}$ in the United States as a whole. So we are cautious to extrapolate our results to other U.S. areas. Further studies are needed to validate our findings for other regions in the United States.

\section{Literature Cited}

American Floral Endowment. 2008. Customer Targeting. 6 Sept. 2008. <http://www.flora-links. org/pdf/customertargeting.pdf $>$.

Barrow, P. 1994. Marketing to generation X. Canadian Manager. 19:23.
Bartlett, T. 1997. Ads for generation X. Business Week 3539:35.

Behe, B.K., E.H. Moore, A. Cameron, and F.S. Carter. 2003. Repositioning selected herbaceous perennials as indoor flowering potted plants using perceptual mapping. HortScience $38: 460-464$.

Bolle, F. 2001. Why to buy your darling flowers; on cooperation and exploitation. Theory Decis. $50: 1-28$.

Burgoyne, C.B. 1999. Gifts. In: Earle, P.E. and S. Kemp (eds.). The Elgar companion to consumer research and economic psychology. Edward Elgar, Cheltemham, UK.

Burke, D. 2007. Talking flowers to men of Cork Human Flower Project. 21 Sept. 2009. <http:// www.humanflowerproject.com/index.php/weblog/ 2007/07/P8/>.

Cheng, A. and M. Evans. 2009. An in-depth look inside the Twitter world. Sysomos Inc. 7 Oct. 2010. <http://www.sysomos.com/insidetwitter>.

Dennis, J.H. and B.K. Behe. 2007. Evaluating the role of ethnicity on gardening purchases and satisfaction. HortScience 42:262-266.

Dunn, W. 1993. The baby bust: A generation comes of age. Houghton-Mifflin, New York, NY.

Freeman, L. 1995. No tricking the media savvy: Individuals 'make appointments' with specific media. Advert. Age 66:30.

Gonzalez, N. 2010. Check Facebook. 6 Oct. 2010. $<$ http://www.checkfacebook.com>.

Huang, M.H. and S. Yu. 2000. Gifts in a romantic relationship: A survival analysis. J. Consum. Psychol. 9:179-188.

IBISWorld, Inc. 2010. Industry report: Florists in the US. IBISWorld, Inc., Santa Monica, CA.

Kerin, R.A., S.W. Hartley, and W. Rudelius. 2009. Marketing: The core. 3rd Ed. McGraw-Hill, New York, NY.

Littrell, M.A., Y.J. Ma, and J. Halepete. 2005. Generation X, baby boomers, and swing: Marketing fair trade apparel. J. of Fashion Mktg. and Mgt. 9:407-419.
Maciejewski, J.J. 2004. Is the use of sexual and fear appeals ethical? A moral evaluation by generation Y college students. J. of Current Issues and Res. in Advertising. 26:97-105.

Morton, L.P. 2002. Targeting generation Y. Public Relations Qrtly. Summer:46-48.

Nagle, T.T., J.E. Hogan, and J. Zale. 2009. The strategy and tactics of pricing: A guide to growing more profitably. Prentice Hall, Upper Saddle River, NJ.

Oppenheim, P. 2000. Segmentation and target marketing in a floral market. Acta Hort. 536:529-536.

Parson, A.G. 2002. Brand choice in gift giving: Recipient influence. J. of Product and Brand Mgt. 11:237-249.

Paul, P. 2001. Getting inside gen Y. Amer. Demographics. 42-49.

Robben, H.S.J. and T.M.M. Verhallen. 1994. Behavioral costs as determinants of cost perception and preference formation for gifts to receive and gifts to give. J. Econ. Psychol. 15:333-350.

Roberts, J.A. 1998. Compulsive buying among college students: An investigation of its antecedents, consequences, and implications for public policy. J. Consum. Aff. 32:2.

Roberts, J.A. and C. Manolis. 2000. Baby boomers and busters: An exploratory investigation of attitudes toward marketing, advertising and consumerism. J. of Consumer Mktg. 17:481-497.

Rushkopf, D. 2001. Merchants of cool. WGBH, Boston, MA.

Schiffman, L.G. and L.L. Kanuk. 2007. Consumer behavior. 9th Ed. Prentice, Upper Saddle River, NJ.

Silvergleit, I. 2004. The floriculture industry: A 10year snapshot. Floral Trend Tracker. 8:1-4.

Teigen, K.H., M.V.G. Olsen, and O.G. Solas. 2005. Giver-receiver asymmetries in gift preferences. Br. J. Soc. Psychol. 44:125-144.

Yue, C. and B. Behe. 2008. Consumers' preferences for cut-flower color on calendar and noncalendar occasions. HortScience 45:78-82.

YouTube. 2010. YouTube fact sheet. 6 Oct. 2010. $<$ http://www.youtube.com/t/fact_sheet $>$. 